\title{
最大酸素摂取量と左心室および大動脈形態との関係

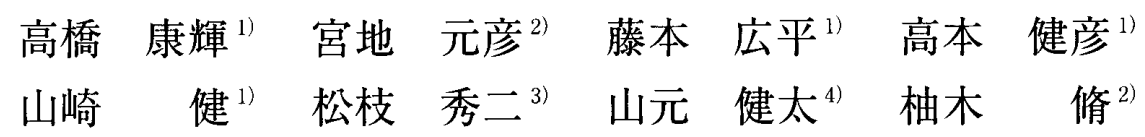

\section{Maximal oxygen uptake is associated with dimensions in left ventricle and aorta}

\author{
Kouki Takahashi ${ }^{1}$, Motohiko Miyachi ${ }^{2}$, Kouhei Fujimoto ${ }^{1}$, Takehiko Takamoto ${ }^{1}$, \\ Ken Yamazaki ${ }^{1}$, Shuji Matsueda ${ }^{3}$, Kenta Yamamoto ${ }^{4}$ and Osamu Yuzuki ${ }^{2}$
}

\begin{abstract}
Endurance-trained athletes with higher aerobic power ( $\left(\mathrm{Vo}_{2} \mathrm{max}\right)$ have a large-sized left ventricle (LV) and aorta (Ao). We therefore hypothesized that the individual variability of $\dot{\mathrm{V}}_{2}$ max can be estimated using resting LV and Ao dimensions. In looking at this question we performed a laboratorybased cross-sectional study to determine the relationship between $\dot{V}_{2}$ max, LV dimensions, and Ao dimensions in young subjects with wide ranges of physical activity status. One hundred forty-two healthy young men (20-35 years), who were either sedentary, recreationally active or endurancetrained, participated in the cross-sectional study. Subsequently, a meta-analysis approach was used to collect 28 studies involving 58 groups and 816 subjects. LV and Ao dimensions were determined by echocardiography at supine rest. In the cross-sectional study and meta-analysis, LV end-diastolic diameter (LVEDD) and end-systolic diameter (LVESD), posterior wall thickness (PWT) and interventricular septum thickness (IVST), and Ao diameter (AoD) were positively and significantly correlated with $\dot{\mathrm{V}}_{2} \max$. When we performed a stepwise regression analysis in the cross-sectional study to determine independent predictors of $\dot{V}_{2}$ max, the variables entered were LVEDD, AoD, and PWT, which together explained 60-70\% of the variability. Furthermore, we attempted to develop equations for predicting $\mathrm{V}_{2}$ max. Multiple regression analyses using LVEDD, AoD, and PWT as the ex-

1）川崎医療福祉大学大学院医療技術学研究科健康科学専 攻

テ 701-0193 岡山県倉敷市松島 288

2）川崎医療福祉大学医療技術学部健康体育学科

干 701-0193 岡山県倉敷市松島 288

3）川崎医療福祉大学医療技術学部臨床栄養学科

テ 701-0193 岡山県倉敷市松島 288

4) 国立循環器病センター研究

干 565-8565 大阪府吹田市藤白台 5-7-1

連絡先 宮地元彦

（独）国立健康 - 栄養研究所

テ 162-8636 東京都新宿区戸山1-23-1

1. Kawasaki University of Medical Welfare Graduate School, Department of Health Science 288 Matsushima, Kurashiki, Okayama 710-0193

2. Kawasaki University Medical Welfare, Department of Health \& Sports Science

288 Matsushima, Kurashiki, Okayama 710-0193

3. Kawasaki University Medical Welfare, Department of Clinical Nutrition

288 Matsushima, Kurashiki, Okayama 710-0193

4. Department of Cardiovascular Dynamics, National Cardiovascular Center Research Institute.

5-7-1 Fujishirodai, Suita, Osaka 565-8565

Corresponding author miyachi@nih.go.jp
\end{abstract}


planatory variables for predicting $\mathrm{V}_{2}$ max yielded the following equations.

$\dot{\mathrm{Vo}}_{2} \max \left(\mathrm{ml} \cdot \mathrm{min}^{-1} \cdot \mathrm{kg}^{-1}\right)=49.2 \operatorname{LVEDD}(\mathrm{mm} / \mathrm{kg})+27.2 \mathrm{AoD}(\mathrm{mm} / \mathrm{kg})+43.9 \mathrm{IVST}(\mathrm{mm} / \mathrm{kg})$ $-2.6$

These results suggest that the variability of $\mathrm{V}_{2}$ max can be accounted for by differences in both left ventricular and aortic structure. Furthermore, echocardiography at supine-rest was useful for evaluating maximal aerobic power, specifically for young healthy men, who demonstrated a wide range of trained states.

\section{Key words : aerobic power, artery, echocardiography, heart, meta-analysis} (Japan J. Phys. Educ. Hlth. Sport Sci. 48: 691-703, November, 2003)

キーワード：有酸素性作業能力，動脈，超音波心 臓検查法, 心臟, メ夕解析

\section{I 緒言}

持久的競技者の最大酸素摂取量（ $\dot{\mathrm{V}}_{2} \mathrm{max} ）$ は 非活動的な生活習慣を有する人より大きい。また $\dot{\mathrm{V}}_{\mathrm{O}_{2}} \mathrm{max}$ は持久的なトレーニングによって増加す る.これらの生理学的機序として，中枢性と末梢 性の要因が関与するとされており，中枢性の要因 として心臓 (左心室) の機能の向上や形態の変化 があげられる（山地，2001）。激しい全身性のト レーニングを行ってきた持久的競技者の心臓は左 心室内腔拡大や左心室心筋重量の増大に代表され る，いわゆるスポーツ心臓の様相を呈することは よく知られている（Morganroth et al., 1975 ; Adams et al., 1981 ; Rost and Hollmann, 1983 ; Shapiro and Smith, 1983 ; Fagard, 1992).

さらに近年,我々を含むいくつかのグループが, 持久的競技者は非鍛鍊者と比較してより太い上行 大動脈あるいは大腿動脈を有していること（Wijnen et al., 1991 ; Zeppilli et al., 1995)，持久的 トレーニングにより大動脈や大腿動脈の内径が拡 大することを報告している（Miyachi et al., 1998 ; Dinenno et al., 2001 ; Miyachi et al., 2001).大動脈の内径が大きいということは血管 コンダクタンスが大きいことを意味しており，運 動中に抢ける中枢から末梢への血液運搬に好まし い影響を及ぼすと考えられる。
以上の先行研究から, 従来から提唱されている 左心室の形態に加えて, 大動脈の形態も $\mathrm{V}_{\mathrm{O}_{2}} \mathrm{max}$ の個人差に関連していると推測される。そこで本 研究では，様々な身体活動・トレーニング水準に ある 100 名を越える健康な青年男性の $\mathrm{V}_{\mathrm{O}_{2}} \max$ と 超音波エコー装置で測定された左心室および上行 大動脈の形態との関係を横断的実験研究で明らか にし，左心室および上行大動脈の形態から $\dot{V}_{O_{2}} \max$ を推定することが可能か否かを検討する ことを第一の目的とした。さらに，すでに出版さ れた論文に記述された， $\dot{V}_{\mathrm{O}_{2}} \max$ と超音波エコー 装置を用いて測定された心臓及び大動脈形態のパ ラメーターの平均值を利用してメ夕解析を行い, 我々の横断的実験の妥当性を確認することを第二 の目的とした。

\section{II方法}

\section{1. 横断的実験研究}

1）被験者

被験者は様々な身体活動レベルを有する健康な 青年男子 142 名とした。被験者の身体的特徵は， 年齢：21 2 (平均值 \pm 標準偏差) 歳, 身長： $173.3 \pm 5.7 \mathrm{~cm}$ ，体重：66.6 $\pm 8.9 \mathrm{~kg}$ であった。

すべての被験者は肺疾患，心疾患の既往歴がな く，また投薬を受けていないものであった。川崎 医療福祉大学倫理委員会の承認のもと，被験者に は本研究の目的, 方法，危険性を十分に説明し， 研究に参加することの同意を得た.

2）実験手順 


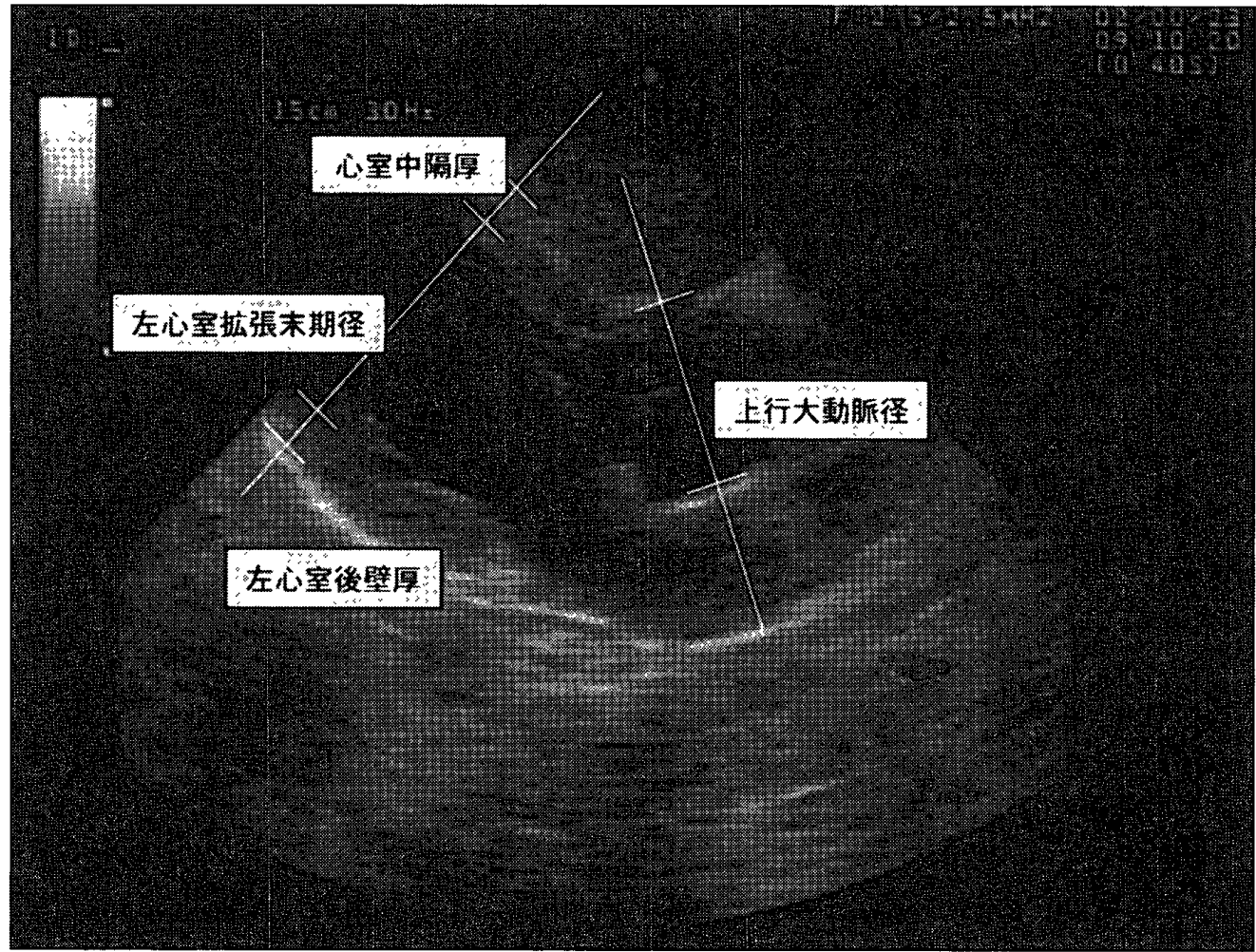

胸骨左縁長軸断面Bモード画像

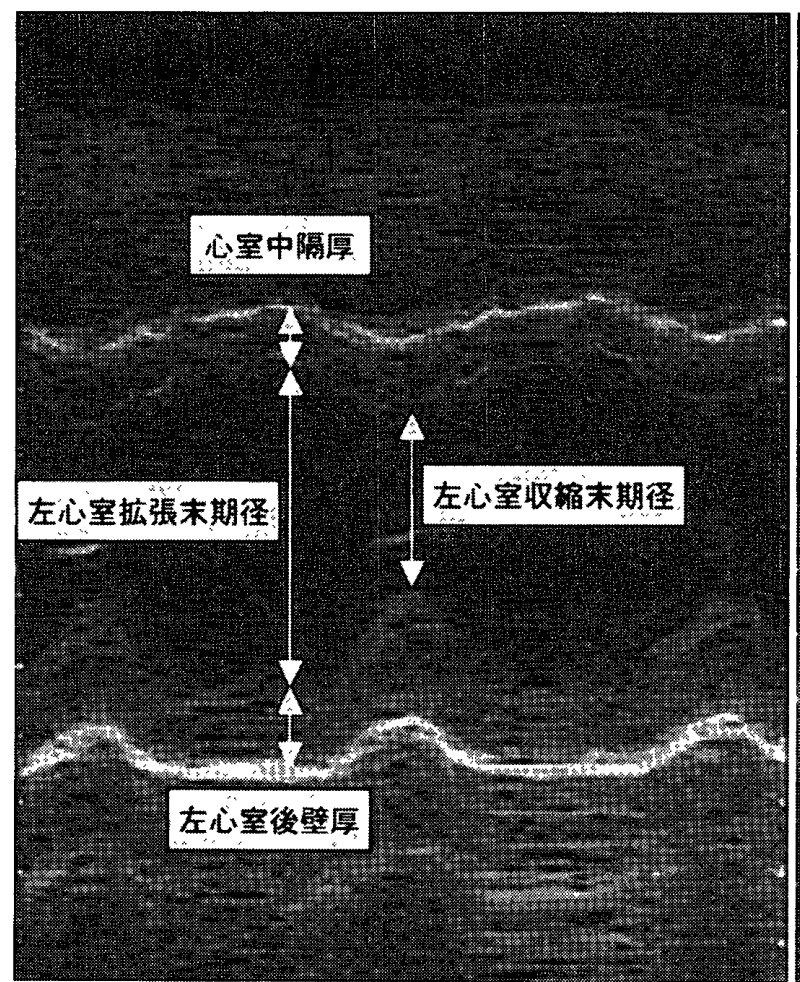

左心室Mモード画像

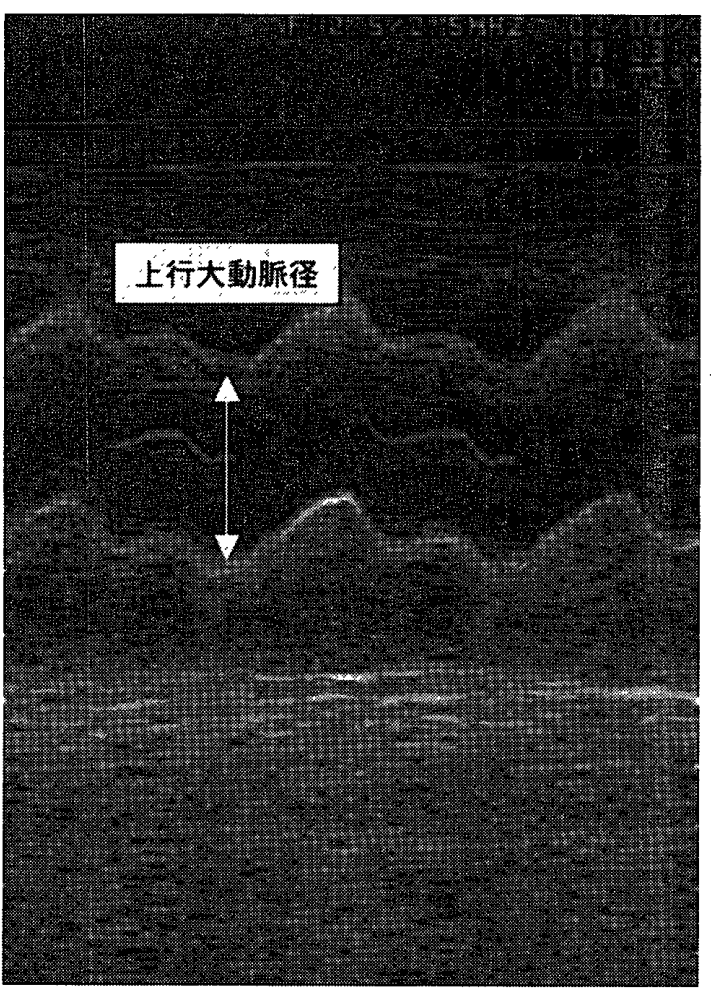

上行大動脈Mモード画像

図1 超音波エコー画像

すべての被験者の仰臥位安静状態における左心 室と上行大動脈の形態を超音波エコー装置で測定 した（3）心蔵血管形態の測定を参照)。超音波工
コー検査の後， $\dot{\mathrm{V}}_{2} \mathrm{max}$ を自転車エルゴメーター を用いた負荷漸増法（4） $\dot{V}_{\mathrm{O}_{2}} \max$ の測定を参照) により測定した。これらの測定で得られた值を回 
帰分析等で多変量解析した (5) 統計処理を参照).

3）心臓血管形態の测定

（1）左心室形態の測定

左心室の内腔および心室壁の形態を超音波エコ 一装置（Aloka Color Doppler SSD-870）を使用 し，仰臥位安静状態にて測定した。 $2.5 \mathrm{MHz}$ ある いは $3.5 \mathrm{MHz}$ の探触子を第 $3-4$ 肋間胸骨左縁に あて, 胸骨左縁長軸断面 B モード画像（図 1 上） を描出し，僧帽弃の拍動が認められ，かつ心室中 隔と左心室後壁が明瞭に描出されるようにBモー ド画像を設定し，左心室内径が最も大きい部分に おける連続5一-10拍の $\mathrm{M}$ モード画像を高密度モ ノクロプリンターを用いて記録した（図1下左）. 拡張末期と収縮末期の左室内腔直径と中隔・後壁 の厚さを測定し，それぞれの平均值より左心室拡 張末期径, 左心室収縮末期径, 心室中隔厚, 左心 室後壁厚を求めた。これらの得られた值を体重で 補正した (単位, $\mathrm{mm} / \mathrm{kg}$ )。

（2）上行大動脈形態の測定

$2.5 \mathrm{MHz}$ あるいは $3.5 \mathrm{MHz}$ の探触子を第 $3-4$ 肋 間胸骨左縁にあてて上行大動脈の内壁が明瞭に描 出されるよう上行大動脈の胸骨左縁長軸断面 Bモ 一ド画像を設定し，大動脈弁前尖がわずかに認め られる位置で連続 5-10拍の M モード画像を記 録した（図 1 下右）。それぞれの拍動の左心室の 拡張末期と収縮末期における大動脈内径を測定 し, 平均值より上行大動脈径を求めた. 上行大動 脈径も左心室形態と同様に体重で補正した(単位, $\mathrm{mm} / \mathrm{kg}$ ).

4) $\dot{\mathrm{V}} \mathrm{O}_{2} \max$ の測定

$\dot{\mathrm{V}}_{\mathrm{O}_{2}} \mathrm{max}$ の測定には自転車エルゴメーター （Monark 818 E）を使用し，プロトコールは 120W から開始し，1分每に $15 \mathrm{~W}$ ずつ強度を高め ていく多段階負荷漸増法で行った. 自転車エルゴ メーターの回転数は 60 回転／分とし，測定時間 は疲労困供に至るまでとした。 心拍数が 170 拍以 上，もしくは主観的運動強度 (RPE ; Rating of Perceived Exertion）が18 以上となってから，採 気を各負荷強度 1 分間の後半 30 秒間行った．運 動強度の増加に対する酸素摂取量の増加と, その レベリングオフ発現を明確にするため最低でも 3
回以上の採気と呼気ガス分析を行った．被験者は 採気開始 15 秒前にマウスピース（model 2100, HANS Rudolph）とノーズクリップを装着し，呼 気ガスが漏れないことを確認してダグラスバッグ に集めた。マウスピースとノーズクリップによる 採気に慣れていない被験者に対しては一部採気マ スクを使用した。呼気ガスの酸素と二酸化炭素の 濃度分析は, 質量分析器 (model WSMR-140, ウ エストロン）により行った。質量分析器は標準ガ スで酸素と二酸化炭素の濃度を校正した後に使用 した。ガス量とガス温は乾式ガスメーター (model DC-5，品川製作所）で測定した．心拍数 は胸部双極誘導法により心電図テレメーター（日 本光電，WEP-7404）で測定した. 実験中，心電 図と心拍数は常に測定し，心拍数の記録は運動開 始から運動終了まで1分毎に行った。測定時の気 圧はフォルタン型水銀指示気圧計（いすず製作所） で測定した．気圧とガス温からSTPD（Standard Temperature Pressure Dry）係数を求め酸素捸 取量を標準状態での值に補正した。各負荷強度で 得られた酸素摂取量の最大值を体重で補正し $\dot{\mathrm{V}}_{2} \max \left(\mathrm{ml} \cdot \min ^{-1} \cdot \mathrm{kg}^{-1}\right)$ とした. $\dot{\mathrm{V}} \mathrm{O}_{2} \max$ の評価基準は，1）レベリングオフが確認される こと，2）年齢から推定される最高心拍数 （220一年齢 55 拍/分以内）にほぼ達しているこ と，3）呼吸交換比>1.0-1.5であること，4） RPEが19あるいは 20 であること，この 4 つの指

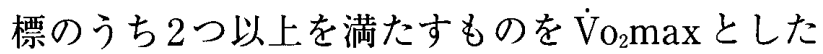
(山地, 2001). 尚, 本実験では全ての被験者がこ の条件を満たしていた。

\section{5）統計処理}

すべての測定値は平均值士標準偏差で表した. 統計解析ソフト Statview（HULINKS 社）を用い て， $\dot{\mathrm{V}}_{2} \max$ と超音波心臓検查装置で計測した各 測定值との間で回帰分析を行った。 $\dot{V}_{O_{2}} \max$ を従 属変数とし, その他の左心室拡張末期径, 左心室 収縮末期径, 心室中隔厚, 左心室後壁厚, 上行大 動脈径を独立变数として単回帰分析を行い，その 相関係数の高い変数から順に独立変数に加えて行 く増加法によるステップワイズ回帰分析を行っ た. ステップワイズ回帰分析で採用となった独立 
変数（段階的に変数を加えて行く際に重回帰相関 係数を増加させる变数)のみで重回帰分析を行い, $\dot{\mathrm{V}}_{\mathrm{O}_{2}} \max$ の予測式を導いた。 全ての検定において， 危険率（p） $5 \%$ 未満を有意とした。

\section{2. メ夕解析 (meta-analysis)}

1）文献の選定

メ夕解析は先行研究の知見を系統的に統合・解 析するための定量的手法とされている. 本研究の メ夕解析において, 最初に, $\dot{\mathrm{V}}_{\mathrm{O}_{2}} \max$ と左心室お よび動脈の形態を超音波法を用いて測定している 先行研究を文献検索システム Medlineを用いて検 索した. key wordsは「maximal oxygen consumptionあるいは $\dot{V}_{o_{2}} \max$ あるいは aerobic fitness あるいは endurance」と「echocardiographyあるいは aortaあるいは aorticあるいは aortal」とした.さらにそこから以下に示す基準を 満たした文献を手作業で選択した，1）被験者は 成人であること（20-69歳），2） $\dot{V}_{2} \max$ を測 定していること，3）超音波法より求めた左心室 あるいは大動脈のいずれかの形態に関するデー夕 を含んでいること，4）被験者は健常者であるこ と，5）体重を測定していること，とした。本メ 夕解析は, 上記の条件を満たした文献総数 28 , 群数 58 , 被験者数 816 人のデー夕に基づいて行っ た。

2）超音波法による測定データ

左心室拡張末期径, 左心室収縮末期径, 心室中 隔厚, 左心室後壁厚, 上行大動脈径の群ごとの平 均值を各文献から抽出した值を体重で補正した (単位, $\mathrm{mm} / \mathrm{kg}$ ).

3）統計処理

統計処理には統計解析ソフト StatView 利用 し, 各文献から抽出された各変数の平均値の関係 を単回帰分析で解析した。各平均值を算出するた めの被験者数は各文献で異なるが，各平均値に重 み付けをせずに，単純に回帰分析を行った，危険 率（p）5\%末満を有意とした。

\section{III 結 果}

\section{1. 横断的実験研究}

$\dot{V}_{\mathrm{O}_{2}} \max$ 従属変数とし, 左心室搪張末期径, 左心室収縮末期径, 心室中隔厚, 左心室後壁厚, 上行大動脈径を独立变数とした単回帰分析による 結果を図 2 に示した。すべての独立変数において $\dot{\mathrm{V}}_{2} \max$ と有意な単相関関係がみられた。

$\dot{\mathrm{V}} \mathrm{O}_{2} \max$ と左心室拡張末期径，左心室収縮末期 径, 心室中隔厚, 左心室後壁厚, 上行大動脈径と の間で変数増加法によるステップワイズ回㷌分析 を行った結果, 左心室拡張末期径, 上行大動脈径, 心室中隔厚が重回帰相関係数を増加させたため独 立変数として採用となり, 左心室収縮末期径，左 心室後壁厚が重回帰相関係数を増加させなかった ため独立変数から棄却された，採用された独立変 数を用いた重回帰分析結果から，以下の $\dot{V}_{\mathrm{O}_{2}} \max$ 推定式を導いた。

$\dot{\mathrm{V}}_{\mathrm{O}_{2} \max }\left(\mathrm{ml} \cdot \mathrm{min}^{-1} \cdot \mathrm{kg}^{-1}\right)=49.2 \times$ 左心室 拡張末期径 $(\mathrm{mm} / \mathrm{kg})+27.2 \times$ 上行大動脈径 $(\mathrm{mm} / \mathrm{kg})+43.9 \times$ 心室中隔厚 $(\mathrm{mm} / \mathrm{kg})-2.6$

本重回㷌式から算出された $\dot{V}_{O_{2}} \max$ の推定值と $\dot{\mathrm{V}} \mathrm{O}_{2} \max$ の実測値との相関係数は 0.83 , 決定係数 は 0.68 を示した（図3)。それぞれのプロットは 回帰直線を中心としてある範囲内でばらついて存 在している。この回帰直線からのばらつきの程度 は回㷌直線からの各データの残差の標準偏差（回 帰残差の標準偏差）で推測できる。それぞれの回 㷌残差の標準偏差が $4.6 \mathrm{ml} \cdot \mathrm{min}^{-1} \cdot \mathrm{kg}^{-1}$ であ った。

\section{2. メ夕解析}

メ夕解析に用いた 28 編の文献リストと抽出し たデータを表 1 に示した。 $\dot{V}_{O_{2}} \max$ の測定法は， トレッドミルテストが $33 \%$ ，自転車エルゴメー ターが $67 \%$ あった。被験者はアスリートが 608 人，非鍛練者が 208 人であった。

メ夕解析の単回帰分析結果を図 4 に示した。メ 夕解析から得た平均值だけのデータはで，平均 值に加え標準偏差が得られたデー夕は、で, 平均 

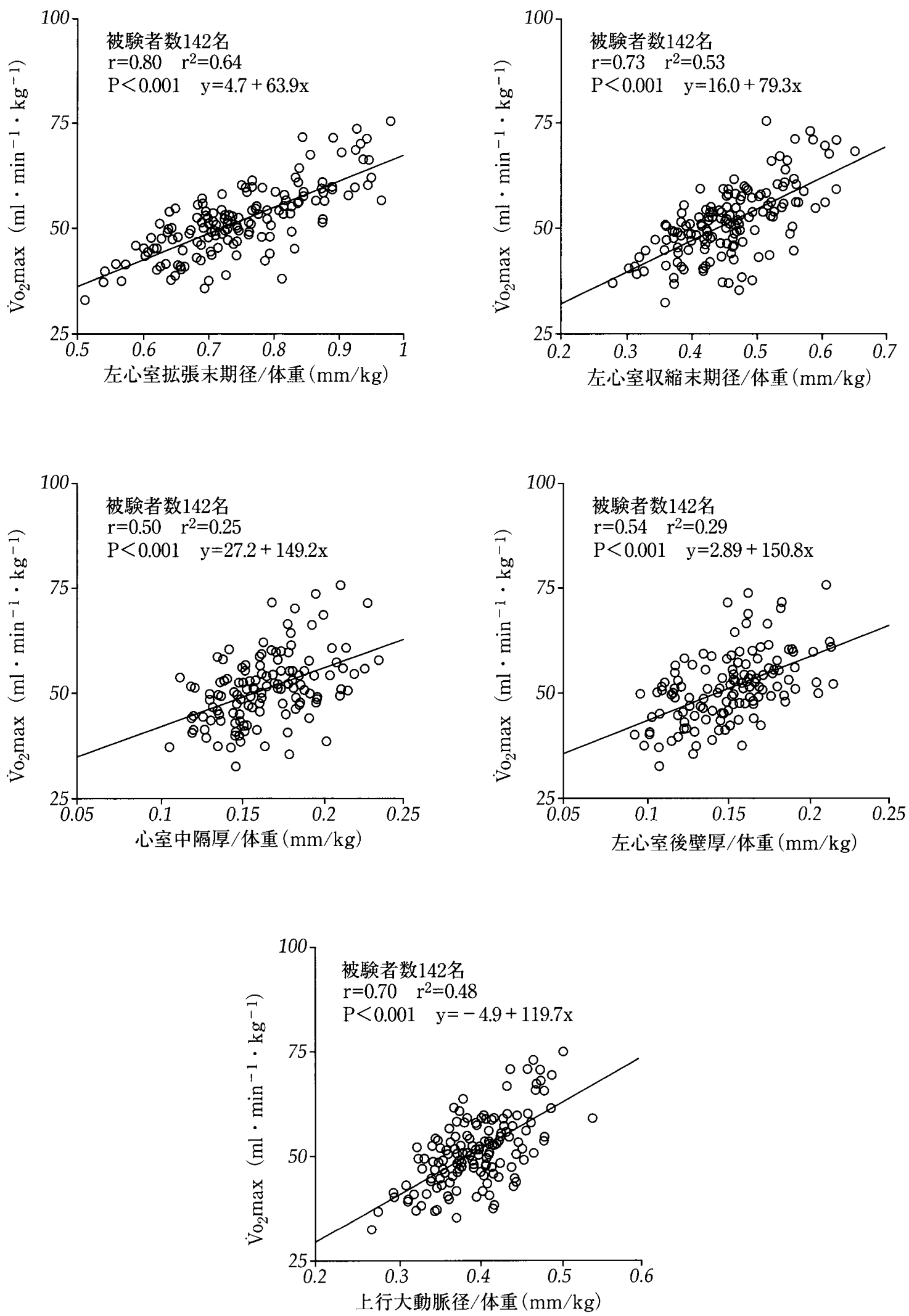

図2 最大酸素摂取量と超音波エコー装置から得られた各測定值間の相関関係 

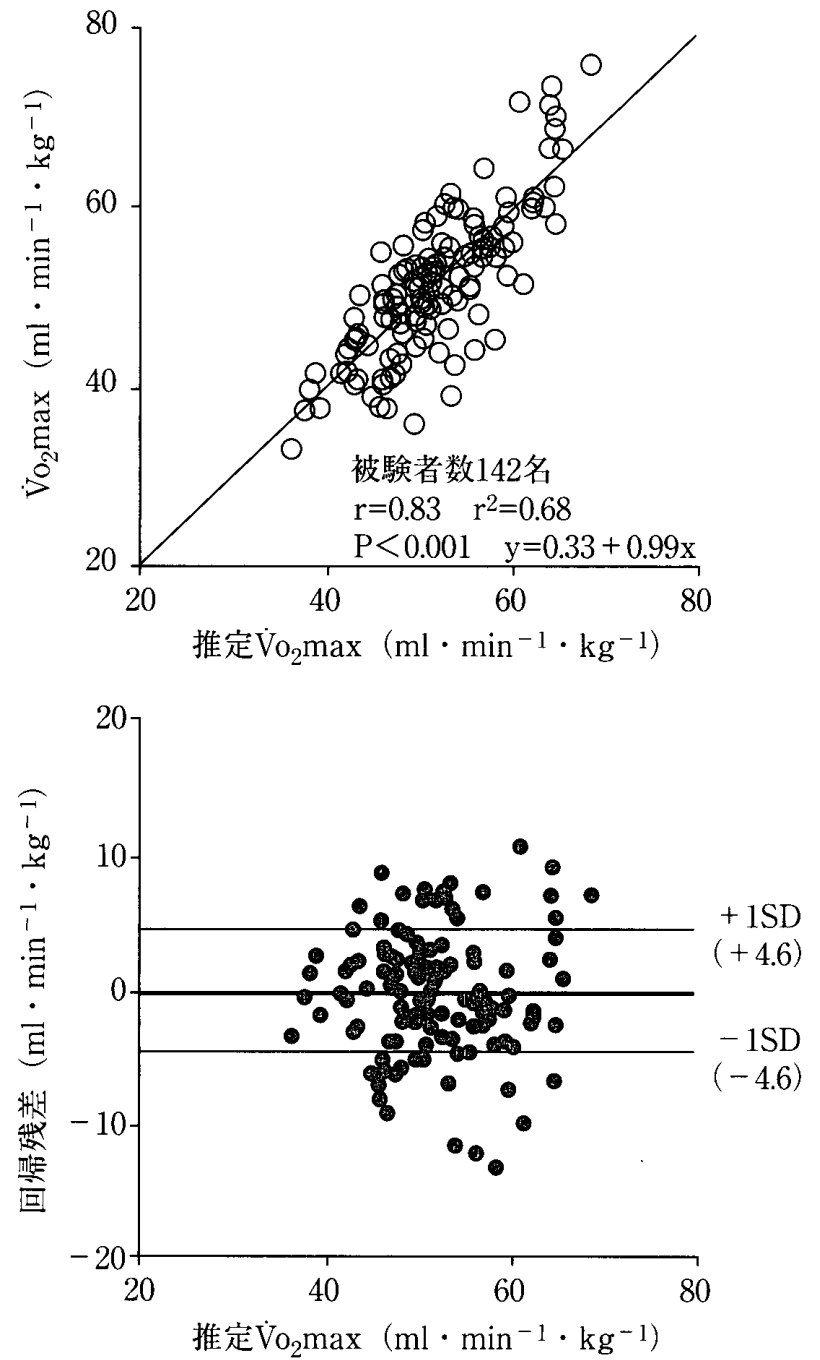

図3 最大酸素摂取量の実測値と推定值との関係（上）と 回帰直線からの残差 (下)

值に加え標準誤差が得られたデー夕は国でプロッ トした．標準偏差あるいは標準誤差が文献から得 られたものに対してはエラーバーを示した。 $\dot{\mathrm{V}} \mathrm{O}_{2} \max$ と左心室拡張末期径, 心室中隔厚, 左心 室後壁厚，上行大動脈径との間には有意な相関関 係が観察された。しかし，左心室収縮末期径との 間には有意な相関関係は観察されなかった。

\section{IV 考察}

本研究で得られた主な知見は以下の通りであ る（1）超音波エコー法で観察した左心室と大動 脈形態から $\dot{\mathrm{V}}_{2} \max$ を以下の式から推定すること が可能である.

$\dot{\mathrm{V}}_{2} \max \left(\mathrm{ml} \cdot \min ^{-1} \cdot \mathrm{kg}^{-1}\right)=49.2 \times$ 左心室
拡張末期径 $(\mathrm{mm} / \mathrm{kg})+27.2 \times$ 上行大動脈径 $(\mathrm{mm} / \mathrm{kg})+43.9 \times$ 心室中隔厚 $(\mathrm{mm} / \mathrm{kg})-2.6$

（2）この推定式で採用された変数は，又夕解 析においても $\dot{V}_{2} \max$ と有意な正の単相関関係に あることから，上記の推定式の妥当性が確認され た。

\section{1. 横断的研究}

全身性の持久的トレーニングを長期にわたり継 続すると心臟は肥大する（Adams et al.，1981； Rost and Hollmann, 1983 ; Shapiro, 1984 ; Huston et al., 1985). 心肥大のうち，持久的卜 レーニングに伴う容量負荷による左心室の内腔の 拡大を特徴とする遠心性肥大が大きな一回拍出量 や $\dot{\mathrm{V}}_{\mathrm{O}_{2} \mathrm{max}}$ と関係している（Grossman et al., 1975 ; Traill et al., 1978 ; Stein et al., 1980). 本横断的実験研究のステップワイズ回帰分析の結 果， $\dot{\mathrm{V}} \mathrm{O}_{2} \max$ を決定づける因子として，上述の生 理学的知見と一致して, 左心室拡張末期径, 心室 中隔厚といった左心室の形態が独立変数として採 用された。さらに，左心室の 2 つの変数の他に， 上行大動脈の直径がステップワイズ解析において 独立変数として採用された，このことは，従来か らよく知られている左心室の内腔や壁の形態だけ ではなく, 上行大動脈の形態的特徵も考慮するこ とで， $\dot{\mathrm{V}}_{\mathrm{O}_{2}} \max$ の推定精度をより高めることがで きることを示唆している。この統計学的結果は, 持久的競技者は非鍛錬者と比較してょり太い上行 大動脈あるいは大腿動脈を有していること（Wijnen et al., 1991 ; Zeppilli et al., 1995)，持久的 トレーニングにより大動脈や大腿動脈の内径が拡 大すること（Miyachi et al., 1998 ; Dinenno et al., 2001 ; Miyachi et al., 2001) といったいく つかの生理学的知見をよく反映している.

本重回帰式から算出された $\dot{V}_{2} \max$ の推定値と $\dot{\mathrm{V}}_{\mathrm{O}_{2}} \max$ の実測值との相関係数は 0.83 で，決定係 数は 0.68 を示した（図 3 )。それぞれのプロット は回帰直線を中心としてある範囲内でばらついて 存在している。この回帰直線からのばらつきの程 度は被験者毎に異なるが, 集団としての推定式か らの誤差は回帰直線からの各データの残差の標準 


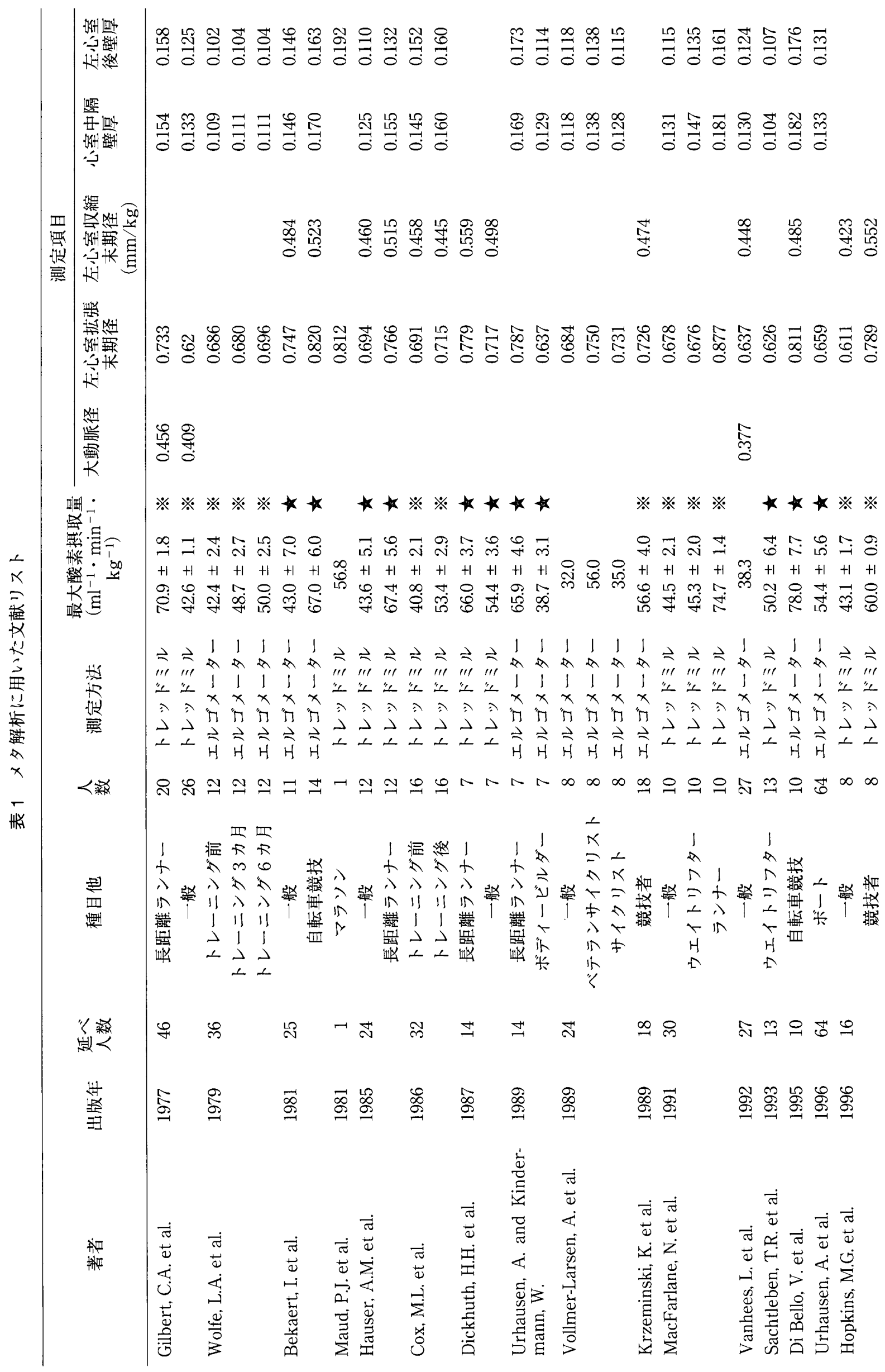




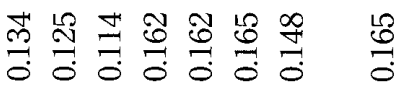

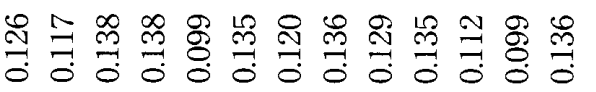

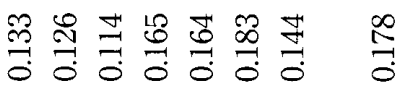

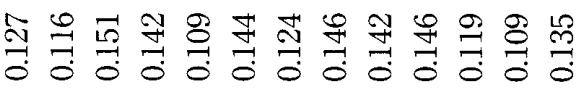

䒿

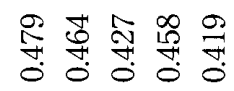

जิ

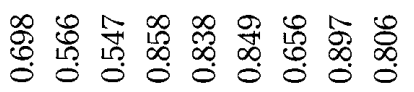

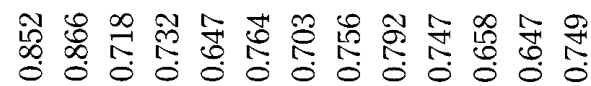

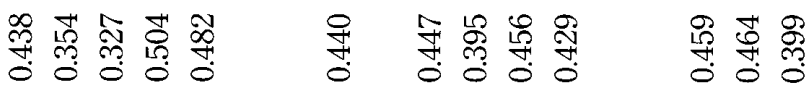

\section{$\star \star \star * ※ ※ *$}

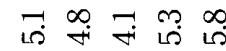

Б)

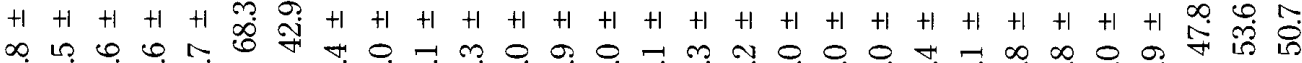

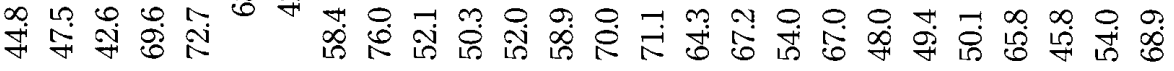

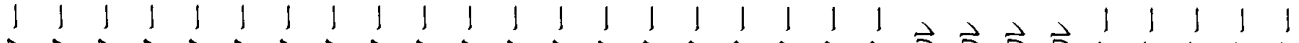

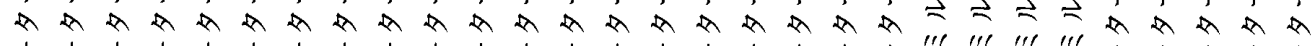

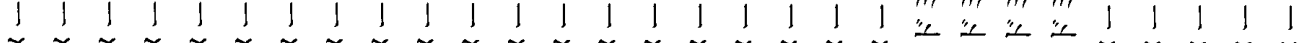

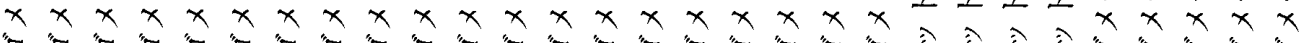

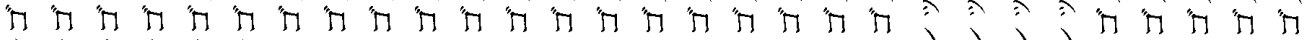
$\vec{H} \vec{H} \underset{H}{\vec{H}} \vec{H} \vec{H} \vec{H} \vec{H} \vec{H} \vec{H} \vec{H} \underset{H}{\vec{H}} \vec{H} \vec{H} \underset{H}{\vec{H}} \vec{H} \vec{H} \vec{H} \perp \pm \perp \perp \vec{H} \vec{H} \vec{H} \vec{H} \vec{H}$ ๗워

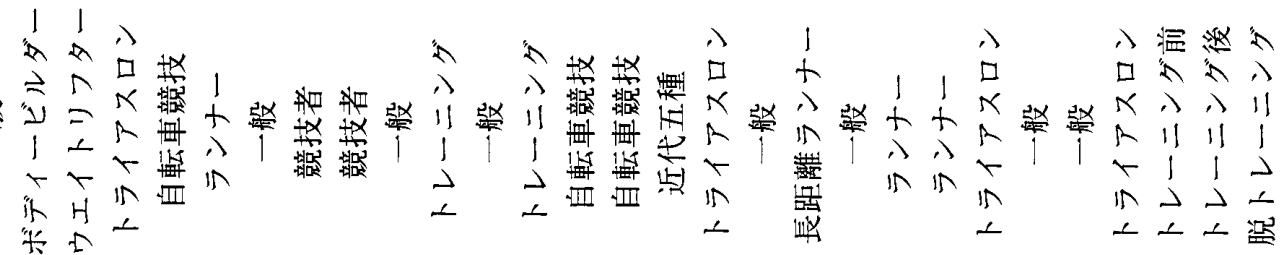

范

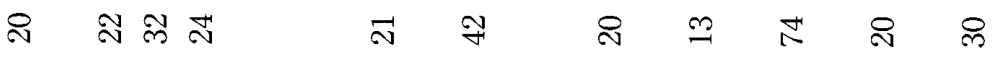

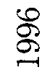

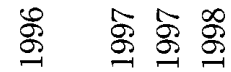

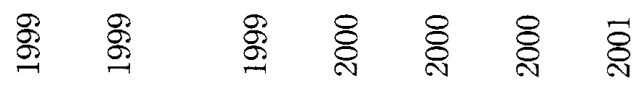

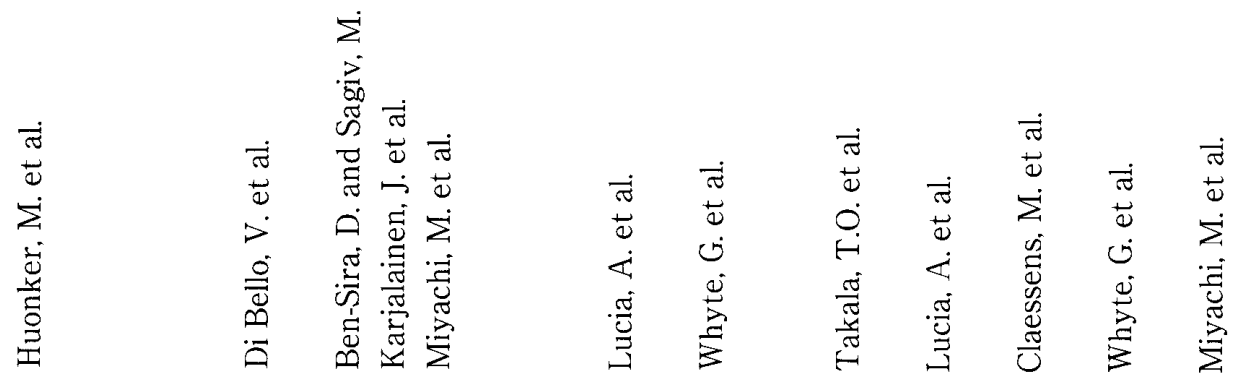



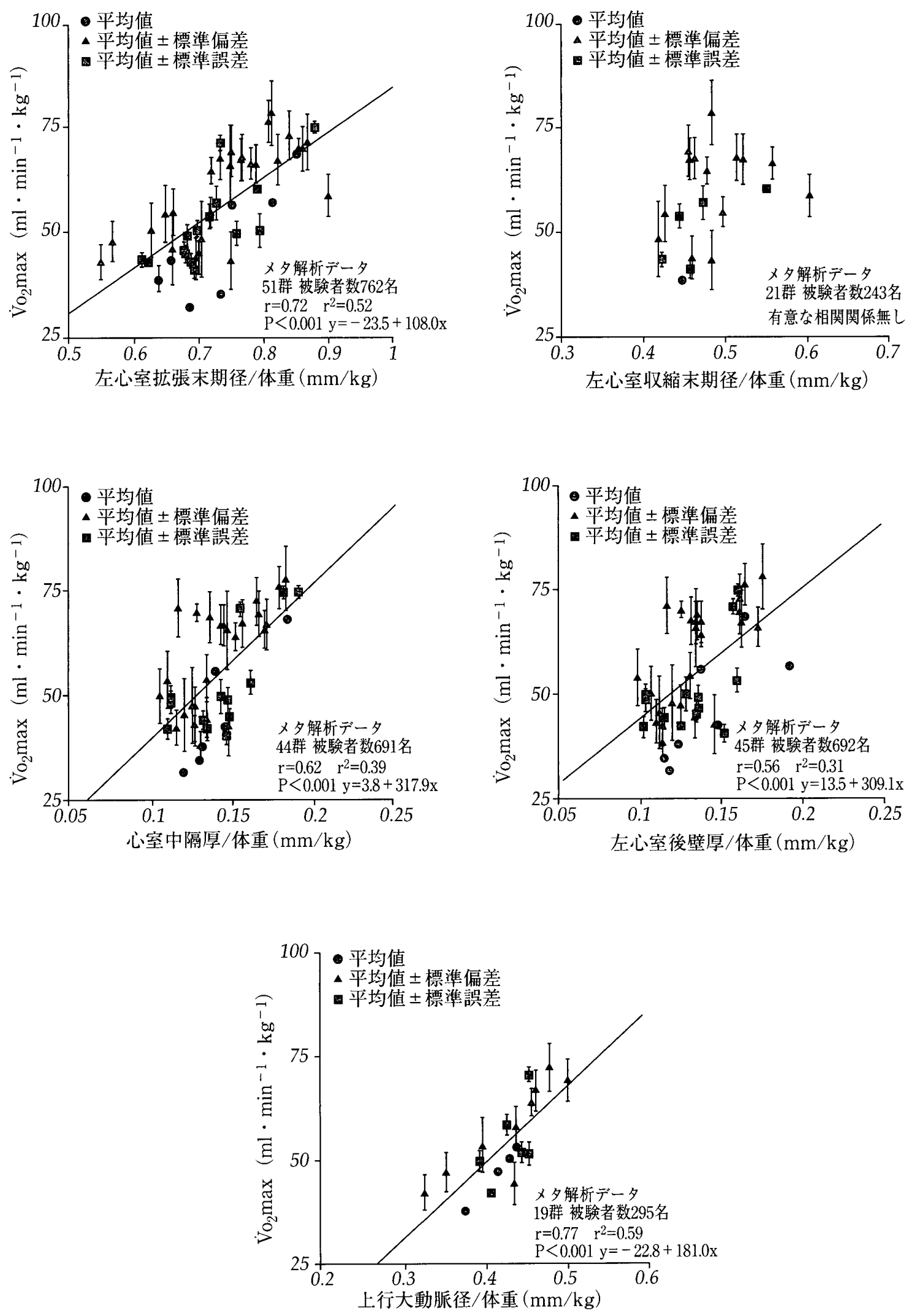

図4メ夕解析で用いた文献より抽出したデータから得られた各測定值間の相関関係 
偏差（回㷌残差の標準偏差）で推測できる. 本研 究では，それぞれの回帰残差の標準偏差が 4.6 $\mathrm{ml} \cdot \mathrm{min}^{-1} \cdot \mathrm{kg}^{-1}$ であった。このような䛊差を 考慮に入れた上で，安静仰臥位における超音波工 コー法を用いることによって，被験者に時間的あ るいは身体的ストレスを与えることなく全身持久 力の推定が可能であると考えられる.

\section{2. メ夕解析}

本メ夕解析では，すでに出版された複数の文献 に示された $\dot{V}_{O_{2}} \max$ と大動脈と左心室形態との関 係を統計学的手法を用いて検討した. $\dot{V}_{\mathrm{O}_{2}} \max$ と 大動脈径や左心室形態の両方との関係を見たメ夕 解析は我々の文献渉猟の範囲ではない。メ夕解析 の問題点として，解析のために採用した文献の間 で測定方法や測定条件が異なることがあげられ る. 具体的には被験者の民族的差異や $\dot{V}_{O_{2}} \max$ 測 定の際の運動負荷方法の違いなどである．その一 方で, メ夕解析では複数の研究施設によって多く の被験者から得られたデー夕を統合的に検討する ことができるといった長所がある。

本メ夕解析において $\dot{\mathrm{V}}_{2} \max$ と, 左心室拡張末 期径は相関係数 0.72 の正の相関が見られた。これ に対して，左心室収縮末期径には有意な相関関係 は観察されなかった。 それに加え， $\dot{V}_{O_{2}} \max$ と心 室中隔厚では相関係数 0.62 , 左心室後壁厚で相関 係数 0.56 の正相関が見られた。これらの相関関係 は, 左心室収縮末期径を除いて, 横断的研究で見 られた同じ変数の相関とほぼ一致していた。我々 の検索した範囲では， $\dot{V}_{2} \max$ と大動脈形態の両 方について記述した論文は 7 編しか抽出すること ができなかった. Pluimらによって行われたスポ 一ツ心臓に関するメ夕解析 (Pluim et al., 2000) においても大動脈のパラメーターに関しては全く 言及されていない。しかし，本メ夕解析結果にお いてプロット数は少ないながらも, $\dot{\mathrm{V}}_{\mathrm{O}_{2}} \max$ と上 行大動脈径との間には相関係数 0.77 という有意な 正の相関関係が見られ，横断的研究と同様の結果 を得た。以上の結果を考え合わせると, 我々の横 断的研究で得られた, 左心室収縮末期径, 心室中 隔厚, 上行大動脈径の 3 つの独立変数で説明され
る推定式が単なる統計学的結果ではなく，従来か ら報告されている多数の生理学的知見をよく反映 した式であると言える。

\section{V 要 約}

本研究では第一に，様々な身体活動・トレーニ ング水準にある142名の健康な青年男性の $\dot{\mathrm{V}}_{\mathrm{O}_{2}} \max$ を超音波装置で測定した左心室および上 行大動脈の形態から推定することが可能か否かを 横断的研究で検討した。第二に，すでに出版され た論文に記述された $\mathrm{V}_{2} \max$ と心臓及び大動脈形 態の超音波形態計測值を利用してメ夕解析を行 い，横断的実験の妥当性を確認した。その結果， 超音波エコー法で観察した左心室と大動脈の形態 から以下の $\mathrm{Vo}_{2} \max$ 推定式が得られた.

$\dot{V}_{O_{2}} \max \left(\mathrm{ml} \cdot \min ^{-1} \cdot \mathrm{kg}^{-1}\right)=49.2 \times$ 左心室 拡張末期径 $(\mathrm{mm} / \mathrm{kg})+27.2 \times$ 上行大動脈径 $(\mathrm{mm} / \mathrm{kg})+43.9 \times$ 心室中隔厚 $(\mathrm{mm} / \mathrm{kg})-2.6$

さらに，この推定式で採用された变数は, メ夕 解析においても $\dot{V}_{2} \max$ と有意な正の単相関関係 にあることから, 本推定式の妥当性を確認するこ とができた. 以上の知見から, 健康な日本人青年 男性の $\dot{V} \mathrm{O}_{2} \max$ ，最大運動負荷試験を行うこと なく, 安静仰臥位での超音波エコー法による左心 室および大動脈の形態計測によって簡便に推測で きることが示唆された。

\section{謝 辞}

本研究は平成 14 年度日本学術振興会科学研究 費補助金（基盤研究 A 14208005），(若手研究 B13780041）および平成 14年度川崎医療福祉大学 プロジェクト研究費の補助を得て遂行された。記 して謝意を表する。

\section{文献}

Adams, T.D., Yanowitz, F.G., Fisher, A.G., Ridges, J.D., Lovell, K., and Pryor, T.A. (1981) Noninvasive evaluation of exercise training in college-age men. Circulation 64: 958-965.

Bekaert, I., Pannier, J.L., Van de Weghe, C., Van 
Durme, J.P., Clement, D.L., and Pannier, R. (1981) Non-invasive evaluation of cardiac function in professional cyclists. Br Heart J 45: 213-218.

Ben-Sira, D. and Sagiv, M. (1997) The effect of gender on left ventricular function immediately after the wingate test. Eur J Appl Physiol Occup Physiol 75: 549-553.

Claessens, M., Claessens, C., Claessens, P., Henderieckx, J., and Claessens, J. (2000) Importance of determining the percentage body fat in endurance-trained athletes. Indian Heart J 52: 307314.

Cox, M.L., Bennett, J.B., 3rd, and Dudley, G.A. (1986) Exercise training-induced alterations of cardiac morphology. J Appl Physiol 61: 926-931.

Di Bello, V., Santoro, G., Talarico, L., Di Muro, C., Caputo, M.T., Giorgi, D., Bertini, A., Bianchi, M., and Giusti, C. (1996) Left ventricular function during exercise in athletes and in sedentary men. Med Sci Sports Exerc 28: 190-196.

Di Bello, V., Talarico, L., Di Muro, C., Santoro, G., Bertini, A., Giorgi, D., Caputo, M.T., Bianchi, M., Cecchini, L., and Giusti, C. (1995) Evaluation of maximal left ventricular performance in elite bicyclists. Int J Sports Med 16: 498-506.

Dickhuth, H.H., Theissen, M., Lehmann, M., AuchSchwelk, W., and Keul, J. (1987) Sensitivity of the physiologically hypertrophied heart to isoproterenol. Int J Sports Med 8: 392-396.

Dinenno, F.A., Tanaka, H., Monahan, K.D., Clevenger, C.M., Eskurza, I., DeSouza, C.A., and Seals, D.R. (2001) Regular endurance exercise induces expansive arterial remodelling in the trained limbs of healthy men. J Physiol 534: 287-295.

Fagard, R.H. (1992) Impact of different sports and training on cardiac structure and function. Cardiol Clin 10: 241-256.

Gilbert, C.A., Nutter, D.O., Felner, J.M., Perkins, J.V., Heymsfield, S.B., and Schlant, R.C. (1977) Echocardiographic study of cardiac dimensions and function in the endurance-trained athlete. Am J Cardiol 40: $528-533$.

Grossman, W., Jones, D., and McLaurin, L.P. (1975) Wall stress and patterns of hypertrophy in the human left ventricle. J Clin Invest 56: 56-64.

Hauser, A.M., Dressendorfer, R.H., Vos, M., Hashimoto, T., Gordon, S., and Timmis, G.C. (1985) Symmetric cardiac enlargement in highly trained endurance athletes: a two-dimensional echocardiographic study. Am Heart J 109: 1038-1044.

Hopkins, M.G., Spina, R.J. and Ehsani, A.A. (1996) Enhanced beta-adrenergic-mediated cardiovascular responses in endurance athletes. J Appl Physiol 80: $516-521$.

Huonker, M., Konig, D., and Keul, J. (1996) Assessment of left ventricular dimensions and functions in athletes and sedentary subjects at rest and during exercise using echocardiography, Doppler sonography and radionuclide ventriculography. Int J Sports Med 17 Suppl 3: S173-S179.

Huston, T.P., Puffer, J.C., and Rodney, W.M. (1985) The athletic heart syndrome. N Engl J Med 313: $24-32$.

Karjalainen, J., Mantysaari, M., Viitasalo, M., and Kujala, U. (1997) Left ventricular mass, geometry, and filling in endurance athletes: association with exercise blood pressure. J Appl Physiol 82: 531-537.

Krzeminski, K., Miskiewicz, Z., Niewiadomski, W., Nazar, K., and Kozlowski, S. (1989) Effect of endurance training on cardiovascular response to static exercise performed with untrained muscles. Int J Sports Med 10: 363-367.

Lucia, A., Carvajal, A., Boraita, A., Serratosa, L., Hoyos, J., and Chicharro, J.L. (1999) Heart dimensions may influence the occurrence of the heart rate deflection point in highly trained cyclists. $\mathrm{Br} \mathrm{J}$ Sports Med 33: 387-392.

Lucia, A., Carvajal, A., Perez, M., and Boraita, A. (2000) Heart rate response during incremental exercise in master runners. Jpn J Physiol 50: 155158.

MacFarlane, N., Northridge, D.B., Wright, A.R., Grant, S., and Dargie, H.J. (1991) A comparative study of left ventricular structure and function in elite athletes. Br J Sports Med 25: 45-48.

Maud, P.J., Pollock, M.L., Foster, C., Anholm, J.D., Guten, G., Al-Nouri, M., Hellman, C., and Schmidt, D.H. (1981) Fifty years of training and competition 
in the marathon: Wally Hayward, age 70-a physiological profile. S Afr Med J 59: 153-157.

Miyachi, M., Iemitsu, M., Okutsu, M., and Onodera, S. (1998) Effects of endurance training on the size and blood flow of the arterial conductance vessels in humans. Acta Physiol Scand 163: 13-16.

Miyachi, M., Tanaka, H., Yamamoto, K., Yoshioka, A., Takahashi, K., and Onodera, S. (2001) Effects of one-legged endurance training on femoral arterial and venous size in healthy humans. J Appl Physiol 90: 2439-2444.

Morganroth, J., Maron, B.J., Henry, W.L., and Epstein, S.E. (1975) Comparative left ventricular dimensions in trained athletes. Ann Intern Med 82: 521-524.

Pluim, B.M., Zwinderman, A.H., van der Laarse, A., and van der Wall, E.E. (2000) The athlete's heart. A meta-analysis of cardiac structure and function. Circulation 101: 336-344.

Rost, R. and Hollmann, W. (1983) . Athlete's heart - a review of its historical assessment and new aspects. Int J Sports Med 4: 147-165.

Sachtleben, T.R., Berg, K.E., Elias, B.A., Cheatham, J.P., Felix, G.L., and Hofschire, P.J. (1993) The effects of anabolic steroids on myocardial structure and cardiovascular fitness. Med Sci Sports Exerc 25: $1240-1245$.

Shapiro, L.M. (1984) Physiological left ventricular hypertrophy. Br Heart J 52: 130-135.

Shapiro, L.M. and Smith, R.G. (1983) Effect of training on left ventricular structure and function. An echocardiographic study. Br Heart J 50: 534-539.

Stein, R.A., Michielli, D., Diamond, J., Horwitz, B., and Krasnow, N. (1980) The cardiac response to exercise training: echocardiographic analysis at rest and during exercise. Am J Cardiol 46: 219-225.

Takala, T.O., Nuutila, P., Katoh, C., Luotolahti, M., Bergman, J., Maki, M., Oikonen, V., Ruotsalainen, U., Gronroos, T., Haaparanta, M. et al. (1999) Myocardial blood flow, oxygen consumption, and fatty acid uptake in endurance athletes during insulin stimulation. Am J Physiol 277: E585-E590.

Traill, T.A., Gibson, D.G., and Brown, D.J. (1978) Study of left ventricular wall thickness and dimension changes using echocardiography. Br Heart J 40: $162-169$.

Urhausen, A. and Kindermann, W. (1989) One- and two-dimensional echocardiography in body builders and endurance-trained subjects. Int J Sports Med 10: 139-144.

Urhausen, A., Monz, T., and Kindermann, W. (1996) Sports-specific adaptation of left ventricular muscle mass in athlete's heart. I. An echocardiographic study with combined isometric and dynamic exercise trained athletes (male and female rowers). Int J Sports Med 17 Suppl 3: S145-151.

Vanhees, L., Hespel, P., Van Hoof, R., Fagard, R., and Amery, A. (1992) Effect of physical training on systemic and brachial artery haemodynamics in normal men. Int J Sports Med 13: 145-151.

Vollmer-Larsen, A., Vollmer-Larsen, B., Kelbaek, H., and Godtfredsen, J. (1989) The veteran athlete: an echocardiographic comparison of veteran cyclists, former cyclists and non-athletic subjects. Acta Physiol Scand 135: 393-398.

Whyte, G., Lumley, S., George, K., Gates, P., Sharma, S., Prasad, K., and McKenna, W.J. (2000) Physiological profile and predictors of cycling performance in ultra- endurance triathletes. J Sports Med Phys Fitness 40: 103-109.

Whyte, G., Sharma, S., George, K., and McKenna, W.J. (1999) Alterations in cardiac morphology and function in elite multi-disciplinary athletes. Int J Sports Med 20: 222-226.

Wijnen, J.A., Kuipers, H., Kool, M.J., Hoeks, A.P., van Baak, M.A., Struyker Boudier, H.A., Verstappen, F.T., and Van Bortel, L.M. (1991) Vessel wall properties of large arteries in trained and sedentary subjects. Basic Res Cardiol 86: 25-29.

Wolfe, L.A., Cunningham, D.A., Rechnitzer, P.A., and Nichol, P.M. (1979) Effects of endurance training on left ventricular dimensions in healthy men. J Appl Physiol 47: 207-212.

山地啓司 (2001) 最大酸素摃取量の科学 改訂第 2 版. 杏林書院：東京, pp. 3-18.

Zeppilli, P., Vannicelli, R., Santini, C., Dello Russo, A., Picani, C., Palmieri, V., Cameli, S., Corsetti, R., and Pietrangeli, L. (1995) Echocardiographic size of conductance vessels in athletes and sedentary people. Int J Sports Med 16: 38-44.

(平成 14 年 8 月 30 日受付) 平成 15 年 4 月 26 日受理 